\title{
Pengaruh Penggunaan Kombinasi Kompos Teh dan Arang Kesambi terhadap Pertumbuhan Tanaman Bayam Hijau (Amaranthus Sp)
}

\author{
Apolinaris Banu ${ }^{\mathrm{a}}$, dan Anna Tefa ${ }^{\mathrm{b}}$ \\ ${ }^{a}$ Fakultas Pertanian, Universitas Timor, Kefamenanu, TTU - NTT, Indonesia. \\ ${ }^{b}$ Fakultas Pertanian, Universitas Timor, Kefamenanu, TTU - NTT, Indonesia.
}

\section{Article Info}

Article history:

Received 8 Februari 2018

Received in revised form 19 Maret 2018

Accepted 4 April 2018

\section{Keywords:}

Kompos Teh

Arang Kesambi

Bayam Hijau

\section{Abstrak}

Bayam hijau merupakan salah satu sayuran daun terpenting di Asia dan Afrika. Pupuk yang sangat baik bagi pertumbuhan bayam adalah pupuk organik. Pupuk organik yang dikenal salah satunya adalah teh kompos yang dapat dikombinasikan dengan arang kesambi. Penelitian ini bertujuan untuk mengetahui pengaruh teh kompos dan arang kesambi terhadap pertumbuhan bayam hijau. Penelitian menggunakan rancangan acak kelompok (RAK) faktorial. Faktor pertama adalah arang kesambi yang terdiri dari tiga level, yaitu kontrol, $5 \mathrm{t} / \mathrm{ha}, 10 \mathrm{t} / \mathrm{ha}$ Faktor kedua adalah konsentrasi teh kompos yang terdiri dari tiga level, yaitu: kontrol, 1:5, 1:10. Teh kompos diberikan setiap minggu semenjak tanaman berumur 7 sampai 28 hari. Penelitian ini dilaksanakan pada bulan Januari - Februari 2017 di lahan percobaan Fakultas Pertanian, Universitas Timor. Hasil penelitian menunjukkan bahwa pemberian arang kesambi $5 \mathrm{t} / \mathrm{ha}$ dan teh kompos dengan konsentrasi perbandingan 1:5 secara nyata memberikan hasil tanaman terbaik yaitu pada bobot segar tanaman (122,30 g) dan bobot segar tajuk (106,24 g). (92018 dipublikasikan oleh Savana Cendana.

\section{Pendahuluan}

Bayam hijau merupakan salah satu sayuran daun terpenting di Asia dan Afrika. Sayuran ini mengandung sumber kalsium, zat besi, vitamin A dan Vitamin C. Bayam hijau adalah tanaman yang berumur pendek dan dapa dibudidayakan dengan mudah di pekarangan rumah atau lahan pertanian. Selain digunakan sebagai sayur, bayam hijau juga dapat digunakan sebagai bahan obat tradisional dan kecantikan. Daun dan bunga bayam berduri berkhasiat dalam pengobatan penyakit asma. Akar bayam hijau dapat digunakan sebagai obat disentri. Sebagai bahan pengobatan luar, bayam hijau dapat dijadikan campuran bahan kosmetika (Rukmana, 1994). Dewasa ini dalam budidaya bayam, umumnya masyarakat menggunakan pupuk kimia sintetik. Masalah lain yang patut diperhatikan dalam penggunaan pupuk kimia di Indonesia adalah adanya indikasi proses pengurangan kandungan 10 jenis unsur hara meliputi sebagian unsur hara makro yaitu N, P dan $\mathrm{K}$ serta unsur hara mikro yaitu $\mathrm{Fe}, \mathrm{Na}, \mathrm{Mo}, \mathrm{Cu}$ $\mathrm{Mg}, \mathrm{S}$ dan Ca (Suriatna, 2002). Berdasarkan hal tersebut makin berkembang alasan untuk mengurangi penggunaan pupuk kimia. Salah satu solusi dari pengurangan pupuk kimia adalah melakukan pembudidayaan tanaman dengan sistem pertanian organik

Menurut Suriatna, (2002), pupuk an-organik atau kimia sintetik mampu meningkatkan produktivitas tanah dalam waktu singkat, tetapi akan mengakibatkan kerusakan pada struktur tanah (tanah menjadi keras) dan menurunkan produktivitas tanaman yang dihasilkan, sedangkan bayam merupakan tanaman yang mudah menyerap pupuk kimia. Hal ini akan berdampak pada kesehatan manusia yang menyebabkan penyakit. Pupuk yang sangat baik bagi pertumbuhan bayam adalah pupuk organik (Sinaga, 2010).

Pupuk organik yang dikenal salah satunya adalah teh kompos yang dapat dikombinasikan dengan arang kesambi. Teh kompos berasal dari kompos pada dan hijauan daun, sedangkan arang terbentuk dari sisa-sisa pembakaran kayu kesambi yang berfungsi sebagai pemadat tanah. Penggunaan teh kompos sebagai pupuk sangat baik karena dapat memberikan manfaat antara lain menyediakan unsur hara bagi tanaman, menggemburkan tanah, memperbaiki struktur dan tekstur tanah, meningkatkan daya ikat tanah terhadap air, memudahkan pertumbuhan akar tanaman, menyimpan air tanah lebih lama, mencegah lapisan kering pada tanah, mencegah beberapa penyakit akar, harganya lebih murah, berkualitas dan ramah lingkungan, pemakaiannya lebih hemat, bersifat mult lahan karena bisa digunakan di lahan pertanian, perkebunan dan reklamasi lahan kritis (Irwan et al., 2015).

Selain itu dalam teh kompos terdapat mikroorganisme yang menguntungkan yaitu jamur dan bakteri. Jamur yang berhasil di identifikasi terdapat dalam kompos adalah jamur Mucor sp, Rhizopus, Aspergillus sp, sedangkan bakteri adalah Bacillus sp, Enterobacter sp, Eschericia coli (Yuli et al., 2003).

Arang kesambi dapat membantu pertumbuhan tanaman sehingga menjadi subur, karena arang merupakan pengatur kesuburan tanah. Menurut (Ogawa, 1994), arang aktif efektif dalam meningkatkan sifat fisik tanah seperti agrega tanah dan kemampuan tanah mengikat air. Pada tanah berliat, arang aktif dapat membantu menurunkan kekerasan tanah dan mempertinggi kemampuan pengikatan air tanah, sehingga berpengaruh terhadap peningkatan aktivitas mikroorganisme tanah. Di dalam tanah, arang aktif memainkan peranan sebagai rumah untuk mikroorganisme. Pori-pori kecil pada karbon aktif digunakan sebagai tempat tinggal bakteri, sedangkan pori besar dan retakan digunakan sebagai tempat berkumpulnya mikroorganisme. Penggunaan arang aktif di lahan dapat meningkatkan jumlah bakteri dalam tanah terutama di sekitar aka tanaman pangan. Arang akan mengikat secara baik setiap unsur baik tanaman yang melewatinya dan akan memberikan nutrisi tersebut pada tanaman.

Penggunaan pupuk kimia sebaiknya harus dikurangi, sehingga penggunaan pupuk organik seperti teh kompos yang dikombinasikan dengan arang kesamb dapat meningkatkan pertumbuhan hasil tanaman bayam. Penelitian (Bria, 2016) telah membuktikan bahwa aplikasi kompos teh pada tanaman bayam merah meningkatkan pertumbuhan tanaman (jumlah daun) dan hasil (berat segar total) berkisar dari 106,9-126,3\% dan 136,6\%-237,3\%. Tujuan dari penelitian in adalah untuk mengetahui pengaruh penggunaan kombinasi teh kompos dan arang kesambi terhadap pertumbuhan tanaman bayam hijau.

\section{Metode}

Penelitian ini dilaksanakan pada bulan Januari sampai Februari 2017, di Kebun percobaan Fakultas pertanian, Universitas Timor, Kelurahan Sasi, Kecamatan Kota Kefamenanu, Kabupaten Timor Tengah Utara (TTU). Bahan yang di gunakan dalam penelitian ini adalah benih bayam hijau, kotoran sapi kering, daun gamal (Gliricidia sepium), daun kirinyu (Chromolaena odorata), arang kesambi, EM4 dan air. Alat yang digunakan adalah aerator, cangkul, parang, meter, tali rafia, ember, gembor, termometer, timbangan, oven, alat tulis dan saringan.

Penelitian ini menggunakan Rancangan Acak kelompok (RAK) faktorial. Faktor pertama adalah arang kesambi yang terdiri dari tiga aras, yaitu kontrol 0 $\mathrm{t} / \mathrm{ha}\left(\mathrm{a}_{0}\right), 5 \mathrm{t} / \mathrm{ha}\left(\mathrm{a}_{1}\right), 10 \mathrm{t} / \mathrm{ha}\left(\mathrm{a}_{2}\right)$. Faktor kedua adalah teh kompos dan air yang terdiri dari tiga aras, yaitu: konsentrasi 0:0 $\left(\mathrm{k}_{0}\right), 1: 5\left(\mathrm{k}_{1}\right), 1: 10\left(\mathrm{k}_{2}\right)$. Kombinasi perlakuannya adalah $\mathrm{a}_{0} \mathrm{k}_{0}, \mathrm{a}_{0} \mathrm{k}_{1} \mathrm{a}_{0} \mathrm{k}_{2}, \mathrm{a}_{1} \mathrm{k}_{0}, \mathrm{a}_{1} \mathrm{k}_{1}, \mathrm{a}_{1} \mathrm{k}_{2}, \mathrm{a}_{2} \mathrm{k}_{0}, \mathrm{a}_{2} \mathrm{k}_{1}, \mathrm{a}_{2} \mathrm{k}_{2}$. Perlakuan ini di ulang tiga kali sehingga terdapat 27 satuan percobaan.

Proses pembuatan kompos dilakukan dengan cara kotoran sapi dicampur secara merata dengan hijauan daun yang telah di haluskan kemudian disirami sambil diaduk secara merata dengan air yang di dalamnya telah dilarutkan EM4 dan gula cair. Adonan kemudian dibuat tumpukan setebal 2-3 cm, ditutup dengan karung dan dibalik setiap 3 hari. Sedangkan pembuatan teh kompos dilakukan dengan cara air bersih disiapkan dalam ember sebanyak $10 \mathrm{l}$, selanjutnya $1 \mathrm{~kg}$ kompos yang telah dibungkus dengan kain kasa dimasukkan ke dalam embe tersebut, dan ditambahkan larutan gula $50 \mathrm{ml}$. Campuran tersebut diaduk selama 24 jam menggunakan aerator. Setelah 24 jam (1 hari), teh kompos yang harum baunya disaring menggunakan saringan air dan siap untuk diaplikasikan.

Areal yang digunakan untuk bedengan terlebih dahulu dibersihkan dari gulma, kemudian dilakukan pengolahan tanah. Pembuatan bedengan sesuai petak perlakuan $100 \mathrm{~cm} \times 120 \mathrm{~cm}$. Pemberian arang kesambi di berikan 4 minggu sebelum tanam sesuai dosis perlakuan, kemudian diratakan dengan tanah. Setelah bibit tanaman bayam hijau berumur 21 hari di persemaian, maka bibit tanaman bayam hijau tersebut dipindahkan ke petak percobaan yang berukuran $100 \times 120 \mathrm{~cm}$ dengan jarak tanam $20 \times 20 \mathrm{~cm}$, kemudian tanah di sekitar lubang dipadatkan dan diratakan agar tidak terdapat rongga udara di antara akar dan tidak terjadi genangan air. Bibit yang dipindahkan kelapangan adalah bibit yang mempunyai pertumbuhan yang baik yang berbatang lurus, daunnya hijau mengkilap dan jumlah daunnya 3-5 helai daun atau berumur 21 hari serta bebas hama dan penyakit. Penanaman dilakukan pada sore hari agar tanaman tidak mengalami kelayuan. Penyiraman dilakukan pagi dan sore kecuali pada hari pemberian teh kompos dilakukan. Penyiraman dilakukan dengan menggunakan botol semprot agar volume air yang diberikan pada setiap tanaman sama.

Kegiatan pemeliharaan meliputi penyiraman, penyulaman, pembersihan gulma dan pengendalian hama penyakit. Penyiraman dilakukan sehari 2 kal yaitu pagi dan sore kecuali dalam kondisi hari hujan. Penyulaman dilakukan 7 hari setelah tanam untuk benih yang tidak normal atau tanaman yang mati, sedangkan pengendalian gulma dilakukan secara manual. Pengendalian hama dan penyakit di lakukan sesuai kondisi gejala serangan.

Teh kompos diberikan pada pagi hari sekitar jam 7-9, dimulai dari tanaman berumur 7 HST (hari setelah tanam) dan dilakukan setiap 7 hari sekali hingga tanaman berumur 28 hari (seminggu sebelum panen). Aplikasi sesuai dengan perlakuan. Panen dapat dilakukan setelah tanaman berumur 35 HST (hari setelah tanam). Pemanenan dilakukan dengan cara memotong bagian pangkal batang. Parameter pengukuran dalam penelitian ini adalah:

a. Suhu tanah $\left({ }^{\circ} \mathrm{C}\right)$

Suhu tanah diukur dengan cara menancapkan termometer suhu tanah pada kedalaman $5 \mathrm{~cm}$ selama 3 menit pada tiga titik untuk setiap petak, pada siang hari pukul 12.00-14.00 WITA dan dicatat suhunya. Selama penelitian pengukuran suhu tanah sebanyak empat kali yakni pada 7, 14, 21 dan 28 HST. Pengukuran suhu tanah dilakukan sesuai petunjuk (Budhyastoro et al., 2006). 
b. PH tanah

Sampel tanah diambil dari 5 titik di tiap petak, dikering-anginkan selama 2 minggu dihaluskan dan diayak dengan ayakan diameter $0,5 \mathrm{~mm}$. Contoh tanah halus ditimbang $100 \mathrm{~g}$, ditambahkan akuades $10 \mathrm{ml}$, diaduk dan dibiarkan selama 30 menit, kemudian diaduk lagi lalu diukur pHnya dengan $\mathrm{pH}$ meter.

c. Daya Hantar Listrik (DHL) tanah $\left(\mathrm{dS} / \mathrm{m}^{2}\right)$

Sampel tanah diambil dari 5 titik di tiap petak, dikering-anginkan, dihaluskan dan diayak dengan ayakan diameter $0,5 \mathrm{~mm}$. Contoh tanah halus ditimbang $100 \mathrm{~g}$, ditambahkan akuades $10 \mathrm{ml}$, diaduk dan diukur DHLnya dengan DHL meter.

d. Tinggi tanaman $(\mathrm{cm})$

Pengukuran tinggi tanaman pada umur 7 HST, 14 HST, 21 HST, dan 28 HST dengan Cara menempatkan penggaris pada permukaan tanah dan mengukur sampai bagian tanaman yang tertinggi.

e. Jumlah daun (helai)

Jumlah daun dihitung semua daun yang terbentuk pada tanaman sampel, pada 7 HST, 14 HST, 21 HST, dan 28 HST.

f. Diameter batang $(\mathrm{cm})$

Pengukuran diameter batang dilakukan dengan menggunakan jangka sorong dengan cara menjepit pada bagian batang ( $1 \mathrm{~cm}$ di atas pangkal batang) dari tanaman sampel pada tiap-tiap petak saat 7HST, 14 HST, 21 HST, dan 28 HST. g. Luas daun $\left(\mathrm{cm}^{2}\right)$

Luas daun diukur saat pertumbuhan vegetatif maksimum yakni saat tanaman berumur 35 HST. Pengukuran luas daun menggunakan metode fotografi dengan cara mengambil semua daun pada dua tanaman korban pada tiap bedeng, kemudian dipotret menggunakan kamera digital. Luas area daun kemudian dihitung menggunakan program ImageJ versi 1.40

h. Panjang akar $(\mathrm{cm})$

Pengukuran Panjang akar dengan menggunakan penggaris yang dilakukan pada tanaman korban sebelum di oven.

i. Berat Segar Tajuk (g)

Bagian tanaman di atas permukaan tanah (bagian tajuk) umur 35 HST, dipotong, dicuci, ditiriskan selanjutnya ditimbang menggunakan timbangan analitik dan mencatat hasilnya.

j. Berat Segar Akar (g)

Seluruh bagian akar yang telah dibersihkan dari tanah, dicuci dengan air, ditiriskan dan timbang dengan timbangan analitik.

k. Berat Segar Tanaman $(\mathrm{g})$

Berat segar hasil pertanaman dihitung dari penjumlahan besar segar tajuk dan berat segar akar.

1. Berat Kering Tajuk (g)

Berat kering tajuk diperoleh dari penimbangan bagian tajuk tanaman yang telah dioven pada suhu $70^{\circ} \mathrm{C}$ selama 48 jam hingga mencapai berat konstan.

m. Berat Kering Akar (g)

Setelah penimbangan berat segar akar dilanjutkan dengan mengeringkannya di oven pada suhu $70^{\circ} \mathrm{C}$ selama 48 jam hingga mencapai berat konstan. Selanjutnya menimbang berat kering akar menggunakan timbangan analitik.

n. Berat Kering Tanaman $(\mathrm{g})$

Berat kering tanaman diperoleh dari penjumlahan berat kering tajuk dan berat kering akar.

o. Indeks panen $(\%)$

Indeks panen dihitung dengan cara membandingkan berat bagian tanaman yang bernilai ekonomis dengan berat seluruh bagian tanaman kemudian dikonversi ke satuan \%. Indeks panen dapat dihitung dengan rumus yang dikemukakan oleh (Yadav et al., 1979).

Data hasil pengamatan kemudian dianalisis dengan menggunakan sidik ragam (anova). Jika terjadi perbedaan nyata atau sangat nyata dilakukan uji lanjut dengan menggunakan Duncan Multiple Rance Test (DMRT) dengan tingkat signifikan 5\% sesuai petunjuk (Gomez \& Gomez, 1984). Analisis data menggunakan program SAS

\section{Hasil dan Pembahasan}

\subsection{Suhu Tanah}

Hasil sidik ragam (anova) menunjukkan bahwa tidak terjadi interaksi antara perlakuan takaran arang kesambi dan konsentrasi teh kompos terhadap pertumbuhan dan hasil tanaman bayam hijau untuk pengamatan suhu tanah. Berdasarkan data Tabel 1. suhu tanah selama penelitian berkisar antara $28-37^{\circ} \mathrm{C}$ dan terus mengalami penurunan yang bervariasi antara dosis perlakuan pada setiap waktu pengamatan. Penurunan suhu tanah tersebut diakibatkan oleh penutupan permukaan tanah oleh tajuk tanaman juga faktor iklim dan curah hujan yang tidak menentu. Pada pengamatan hari ke 14 rata-rata suhu tanah naik, ha ini di sebabkan karena pada pengamatan hari ke 7 hanya mengambil 1 titik, sementara untuk hari ke 14, 21 dan 28 mengamati 3 titik, sehingga pada hari 14 rata-rata suhu meningkat.

\subsection{Daya Hantar Listrik (DHL) Tanah}

Hasil sidik ragam (anova) menunjukkan bahwa tidak terjadi interaksi dan beda nyata antara perlakuan takaran arang kesambi dan konsentrasi teh kompos terhadap pertumbuhan dan hasil tanaman bayam hijau untuk pengamatan DHL Tanah. Data Tabel 2. menunjukkan rata-rata DHL tanah tertinggi pada takaran arang kesambi 10 t/ha dibanding takaran 5 t/ha dan kontrol. Pada pemberian teh kompos DHL tanah tertinggi terdapat pada tanpa pemberian teh kompos (kontrol) dibanding pemberian 1:5 dan 1:10.

\begin{tabular}{|c|c|c|c|c|c|}
\hline \multirow{2}{*}{$\begin{array}{c}\text { Hari } \\
\text { Pengamatan }\end{array}$} & \multirow{2}{*}{$\begin{array}{c}\text { Takaran } \\
\text { Arang } \\
\text { Kesambi }\end{array}$} & \multicolumn{3}{|c|}{ Konsentrasi Teh Kompos } & \multirow[b]{2}{*}{ Rerata } \\
\hline & & Kontrol & K5 (1:5) & $\mathrm{K} 10(1: 10)$ & \\
\hline \multirow{4}{*}{$7 \mathrm{HST}$} & Kontrol & 30,78 & 31,27 & 31,39 & $31,14 \mathrm{a}$ \\
\hline & $5 \mathrm{t} / \mathrm{ha}$ & 30,98 & 31,28 & 30,97 & $31,07 \mathrm{a}$ \\
\hline & $10 \mathrm{t} / \mathrm{ha}$ & 30,66 & 30,89 & 31,21 & $30,92 \mathrm{a}$ \\
\hline & Rerata & $30,80 \mathrm{~b}$ & $31,14 \mathrm{ab}$ & $31,19 \mathrm{a}$ & $(-)$ \\
\hline \multirow{4}{*}{$14 \mathrm{HST}$} & Kontrol & 35,57 & 35,44 & 36,91 & $35,97 \mathrm{a}$ \\
\hline & $5 \mathrm{t} / \mathrm{ha}$ & 36,39 & 35,29 & 37,71 & $36,46 \mathrm{a}$ \\
\hline & $10 \mathrm{t} / \mathrm{ha}$ & 35,79 & 36,73 & 36,51 & $36,34 \mathrm{a}$ \\
\hline & Rerata & $35,91 \mathrm{a}$ & $35,82 \mathrm{a}$ & $37,04 \mathrm{a}$ & $(-)$ \\
\hline \multirow{4}{*}{$21 \mathrm{HST}$} & Kontrol & 31,48 & 30,78 & 30,97 & $31,07 \mathrm{a}$ \\
\hline & $5 \mathrm{t} / \mathrm{ha}$ & 30,90 & 30,66 & 30,30 & $30,62 \mathrm{~b}$ \\
\hline & $10 \mathrm{t} / \mathrm{ha}$ & 31,67 & 30,20 & 31,19 & $31,02 \mathrm{a}$ \\
\hline & Rerata & $31,35 \mathrm{a}$ & $30,54 \mathrm{~b}$ & $30,82 \mathrm{~b}$ & $(-)$ \\
\hline \multirow{4}{*}{$28 \mathrm{HST}$} & Kontrol & 29,36 & 28,66 & 28,85 & $28,95 \mathrm{a}$ \\
\hline & $5 \mathrm{t} / \mathrm{ha}$ & 28,78 & 28,54 & 28,18 & $28,50 \mathrm{~b}$ \\
\hline & $10 \mathrm{t} / \mathrm{ha}$ & 29,55 & 28,08 & 29,07 & $28,90 \mathrm{a}$ \\
\hline & Rerata & $29,23 \mathrm{a}$ & $28,42 \mathrm{~b}$ & $28,70 \mathrm{~b}$ & $(-)$ \\
\hline
\end{tabular}

Keterangan: Angka pada kolom dan baris diikuti huruf sama menunjukkan tidak berbeda pada tingkat nyata $(\alpha) 5 \%$ menurut uji DMRT; (-): Tidak terjadi interaksi antar faktor

Tabel 2. DHL Tanah $\left(\mathrm{dS} / \mathrm{m}^{2}\right)$

\begin{tabular}{lllll}
\hline \multirow{2}{*}{$\begin{array}{c}\text { Takaran Arang } \\
\text { Kesambi }\end{array}$} & \multicolumn{3}{c}{ Konsentrasi Teh Kompos } & \multirow{2}{*}{ Rerata } \\
\cline { 2 - 4 } Kontrol & K5 (1:5) & K10 (1:10) & \\
\hline 5 t/ha & 193,33 & 136,33 & 194,00 & $174,56 \mathrm{a}$ \\
$10 \mathrm{t} / \mathrm{ha}$ & 231,00 & 176,33 & 322,33 & $243,22 \mathrm{a}$ \\
\hline Rerata & 350,67 & 188,67 & 246,33 & $261,89 \mathrm{a}$ \\
\hline
\end{tabular}

Keterangan: Angka pada kolom dan baris diikuti huruf sama menunjukkan tidak berbeda pada tingkat nyata $(\alpha) 5 \%$ menurut uji DMRT; (-): Tidak terjadi interaksi antar faktor.

\subsection{PH Tanah}

Hasil sidik ragam (anova) menunjukkan bahwa tidak terjadi interaksi dan beda nyata antara perlakuan takaran arang kesambi dan konsentrasi teh kompos terhadap pertumbuhan dan hasil tanaman bayam hijau untuk pengamatan $\mathrm{pH}$ tanah. Berdasarkan data Tabel 3. menunjukkan rata-rata pemberian takaran arang kesambi dan konsentrasi teh kompos dengan level yang berbeda cenderung menurunkan $\mathrm{pH}$ tanah.

Tabel 3. pH Tanah

\begin{tabular}{lllll}
\hline Takaran Arang & \multicolumn{3}{c}{ Konsentrasi Teh Kompos } & \multirow{2}{*}{ Rerata } \\
\cline { 2 - 4 } Kesambi & Kontrol & K5 (1:5) & K10 (1:10) & \\
\hline Kontrol & 8,05 & 8,01 & 8,01 & $8,02 \mathrm{a}$ \\
$5 \mathrm{t} / \mathrm{ha}$ & 8,04 & 7,95 & 8,02 & $8,00 \mathrm{a}$ \\
$10 \mathrm{t} / \mathrm{ha}$ & 8,06 & 7,98 & 7,95 & $8,00 \mathrm{a}$ \\
\hline Rerata & $8,05 \mathrm{a}$ & $7,98 \mathrm{a}$ & $7,99 \mathrm{a}$ & $(-)$ \\
\hline
\end{tabular}

Keterangan: Angka pada kolom dan baris diikuti huruf sama menunjukkan tidak berbeda pada tingkat nyata $(\alpha) 5 \%$ menurut uji DMRT; (-): Tidak terjadi interaksi antar faktor.

$\underline{\text { Tabel 4. Tinggi Tanaman }(\mathrm{cm})}$

\begin{tabular}{|c|c|c|c|c|c|}
\hline \multirow{2}{*}{$\begin{array}{c}\text { Hari } \\
\text { Pengamatan }\end{array}$} & \multirow{2}{*}{$\begin{array}{c}\text { Takaran } \\
\text { Arang } \\
\text { Kesambi }\end{array}$} & \multicolumn{3}{|c|}{ Konsentrasi Teh Kompos } & \multirow[b]{2}{*}{ Rerata } \\
\hline & & Kontrol & K5 (1:5) & $\mathrm{K} 10(1: 10)$ & \\
\hline \multirow{4}{*}{7 HST } & Kontrol & 2,79 & 3,23 & 2,88 & $2,97 \mathrm{a}$ \\
\hline & $5 \mathrm{t} / \mathrm{ha}$ & 2,42 & 3,31 & 2,78 & $2,83 \mathrm{a}$ \\
\hline & $10 \mathrm{t} / \mathrm{ha}$ & 2,76 & 3,13 & 2,77 & $2,89 \mathrm{a}$ \\
\hline & Rerata & $2,66 \mathrm{~b}$ & $3,22 \mathrm{a}$ & $2,81 \mathrm{~b}$ & $(-)$ \\
\hline \multirow{4}{*}{14 HST } & Kontrol & 4,88 & 5,96 & 5,42 & $5,42 \mathrm{a}$ \\
\hline & $5 \mathrm{t} / \mathrm{ha}$ & 4,83 & 5,75 & 5,46 & $5,35 \mathrm{a}$ \\
\hline & $10 \mathrm{t} / \mathrm{ha}$ & 4,83 & 6,04 & 4,92 & $5,26 \mathrm{a}$ \\
\hline & Rerata & $4,85 \mathrm{~b}$ & $5,92 \mathrm{a}$ & $5,26 \mathrm{ab}$ & $(-)$ \\
\hline \multirow{4}{*}{$21 \mathrm{HST}$} & Kontrol & 9,92 & 11,75 & 10,83 & $10,83 \mathrm{a}$ \\
\hline & $5 \mathrm{t} / \mathrm{ha}$ & 9,63 & 12,67 & 11,67 & $11,32 \mathrm{a}$ \\
\hline & $10 \mathrm{t} / \mathrm{ha}$ & 9,33 & 12,75 & 9,08 & $10,39 \mathrm{a}$ \\
\hline & Rerata & $9,63 \mathrm{~b}$ & $12,39 \mathrm{a}$ & $10,53 \mathrm{ab}$ & $(-)$ \\
\hline \multirow{4}{*}{$28 \mathrm{HST}$} & Kontrol & 17,42 & 20,92 & 18,92 & $19,08 \mathrm{a}$ \\
\hline & $5 \mathrm{t} / \mathrm{ha}$ & 18,17 & 21,75 & 20,25 & $20,06 \mathrm{a}$ \\
\hline & $10 \mathrm{t} / \mathrm{ha}$ & 16,42 & 22,33 & 16,33 & $18,36 \mathrm{a}$ \\
\hline & Rerata & $17,33 \mathrm{~b}$ & $21,67 \mathrm{a}$ & $18,50 \mathrm{~b}$ & $(-)$ \\
\hline
\end{tabular}

Keterangan: Angka pada kolom dan baris diikuti huruf sama menunjukkan tidak berbeda pada tingkat nyata $(\alpha) 5 \%$ menurut uji DMRT; (-): Tidak terjadi interaksi antar faktor. 


\subsection{Tinggi Tanaman}

Hasil analisis sidik ragam (anova) menunjukkan bahwa tidak terjadi interaksi dan tidak ada beda nyata pada setiap pengamatan terhadap takaran arang kesambi, tetapi pada pengamatan 28 HST menunjukkan nilai tertinggi pada takaran arang kesambi 5t/ha (20,06), sementara untuk konsentrasi teh kompos dengan perbandingan 1:5 rata-rata menunjukkan nilai yang beda nyata dibanding kontrol dan 1:10 (Tabel 4.).

\subsection{Diameter Batang}

Hasil sidik ragam (anova) menunjukkan bahwa tidak terjadi interaksi antara kedua faktor. Rata-rata pengamatan diameter batang pada takaran arang kesambi tidak beda nyata dan memiliki nilai tertinggi pada pengamatan 28HST $(0,60)$. Untuk konsentrasi teh kompos dengan perbandingan 1:5 tidak beda nyata dibanding kontrol dan 1:10 dan memiliki nilai tertinggi pada pengamatan 28 HST $(0,63)$.

$\underline{\text { Tabel 5. Diameter Batang }(\mathrm{cm})}$

\begin{tabular}{|c|c|c|c|c|c|}
\hline \multirow{2}{*}{$\begin{array}{c}\text { Hari } \\
\text { Pengamatan }\end{array}$} & \multirow{2}{*}{$\begin{array}{l}\text { Takaran } \\
\text { Arang } \\
\text { Kesambi }\end{array}$} & \multicolumn{3}{|c|}{ Konsentrasi Teh Kompos } & \multirow{2}{*}{ Rerata } \\
\hline & & Kontrol & K5 (1:5) & K10 $(1: 10)$ & \\
\hline \multirow{4}{*}{7 HST } & Kontrol & 0,23 & 0,26 & 0,23 & $0,24 \mathrm{a}$ \\
\hline & $5 \mathrm{t} / \mathrm{ha}$ & 0,23 & 0,22 & 0,22 & $0,22 \mathrm{a}$ \\
\hline & $10 \mathrm{t} / \mathrm{ha}$ & 0,22 & 0,24 & 0,22 & $0,23 \mathrm{a}$ \\
\hline & Rerata & $0,22 \mathrm{a}$ & $0,24 \mathrm{a}$ & $0,23 \mathrm{a}$ & $(-)$ \\
\hline \multirow{4}{*}{$14 \mathrm{HST}$} & Kontrol & 0,33 & 0,36 & 0,33 & $0,34 \mathrm{a}$ \\
\hline & $5 \mathrm{t} / \mathrm{ha}$ & 0,32 & 0,38 & 0,32 & $0,34 \mathrm{a}$ \\
\hline & $10 \mathrm{t} / \mathrm{ha}$ & 0,32 & 0,34 & 0,32 & $0,33 \mathrm{a}$ \\
\hline & Rerata & $0,32 \mathrm{~b}$ & $0,36 \mathrm{a}$ & $0,32 \mathrm{~b}$ & $(-)$ \\
\hline \multirow{4}{*}{$21 \mathrm{HST}$} & Kontrol & 0,40 & 0,50 & 0,44 & $0,45 \mathrm{a}$ \\
\hline & $5 \mathrm{t} / \mathrm{ha}$ & 0,40 & 0,52 & 0,44 & $0,45 \mathrm{a}$ \\
\hline & $10 \mathrm{t} / \mathrm{ha}$ & 0,45 & 0,46 & 0,39 & $0,44 \mathrm{a}$ \\
\hline & Rerata & $0,42 \mathrm{~b}$ & $0,49 \mathrm{a}$ & $0,42 \mathrm{~b}$ & $(-)$ \\
\hline \multirow{4}{*}{$28 \mathrm{HST}$} & Kontrol & 0,52 & 0,64 & 0,56 & $0,57 \mathrm{a}$ \\
\hline & $5 \mathrm{t} / \mathrm{ha}$ & 0,58 & 0,64 & 0,59 & $0,60 \mathrm{a}$ \\
\hline & $10 \mathrm{t} / \mathrm{ha}$ & 0,53 & 0,61 & 0,55 & $0,56 \mathrm{a}$ \\
\hline & Rerata & $0,54 \mathrm{a}$ & $0,63 \mathrm{a}$ & $0,56 \mathrm{a}$ & $(-)$ \\
\hline
\end{tabular}

Keterangan: Angka pada kolom dan baris diikuti huruf sama menunjukkan tidak berbeda pada tingkat nyata ( $\alpha$ ) $5 \%$ menurut uji DMRT; (-): Tidak terjadi interaksi antar faktor.

\subsection{Jumlah Daun}

Jumlah daun meningkat sesuai dengan umur tanaman. Hasil sidik ragam (anova) menunjukkan bahwa tidak terjadi interaksi antara kedua faktor dan tidak ada beda nyata antara rata-rata perlakuan takaran arang kesambi, untuk pengamatan 28 HST memiliki nilai tertinggi pada pemberian arang kesambi dengan takaran $5 \mathrm{t} / \mathrm{ha}(14,61)$, sementara untuk konsentrasi teh kompos rata-rata memiliki nilai yang beda nyata dan pada pengamatan 28HST menunjukkan nilai tertinggi pada konsentrasi teh kompos 1:5 $(15,00)$ dibanding kontrol dan konsentrasi 1:10.

Tabel 6. Jumlah Daun (helai)

\begin{tabular}{|c|c|c|c|c|c|}
\hline \multirow{2}{*}{$\begin{array}{c}\text { Hari } \\
\text { Pengamatan }\end{array}$} & \multirow{2}{*}{$\begin{array}{c}\text { Takaran } \\
\text { Arang } \\
\text { Kesambi }\end{array}$} & \multicolumn{3}{|c|}{ Konsentrasi Teh Kompos } & \multirow[b]{2}{*}{ Rerata } \\
\hline & & Kontrol & K5 (1:5) & K10 (1:10) & \\
\hline \multirow{4}{*}{$7 \mathrm{HST}$} & Kontrol & 5,42 & 5,08 & 4,75 & $5,08 \mathrm{a}$ \\
\hline & $5 \mathrm{t} / \mathrm{ha}$ & 4,75 & 5,25 & 5,08 & $5,03 \mathrm{a}$ \\
\hline & $10 \mathrm{t} / \mathrm{ha}$ & 5,25 & 5,00 & 4,92 & $5,06 \mathrm{a}$ \\
\hline & Rerata & $5,14 \mathrm{a}$ & $5,11 \mathrm{a}$ & $4,92 \mathrm{a}$ & $(-)$ \\
\hline \multirow{4}{*}{14 HST } & Kontrol & 6,92 & 7,33 & 7,08 & $7,11 \mathrm{a}$ \\
\hline & $5 \mathrm{t} / \mathrm{ha}$ & 7,00 & 6,92 & 7,08 & $7,00 \mathrm{a}$ \\
\hline & $10 \mathrm{t} / \mathrm{ha}$ & 6,75 & 7,75 & 7,08 & $7,19 \mathrm{a}$ \\
\hline & Rerata & $6,89 \mathrm{a}$ & $7,33 \mathrm{a}$ & $7,08 \mathrm{a}$ & $(-)$ \\
\hline \multirow{4}{*}{$21 \mathrm{HST}$} & Kontrol & 9,92 & 11,17 & 10,33 & $10,47 \mathrm{a}$ \\
\hline & $5 \mathrm{t} / \mathrm{ha}$ & 10,67 & 10,83 & 10,67 & $10,72 \mathrm{a}$ \\
\hline & $10 \mathrm{t} / \mathrm{ha}$ & 10,00 & 10,92 & 9,42 & $10,11 \mathrm{a}$ \\
\hline & Rerata & $10,19 \mathrm{~b}$ & $10,97 \mathrm{a}$ & $10,14 \mathrm{~b}$ & $(-)$ \\
\hline \multirow{4}{*}{$28 \mathrm{HST}$} & Kontrol & 14,17 & 14,75 & 14,17 & $14,36 \mathrm{a}$ \\
\hline & $5 \mathrm{t} / \mathrm{ha}$ & 14,33 & 15,08 & 14,42 & $14,61 \mathrm{a}$ \\
\hline & $10 \mathrm{t} / \mathrm{ha}$ & 13,83 & 15,17 & 13,75 & $14,25 \mathrm{a}$ \\
\hline & Rerata & $14,11 \mathrm{~b}$ & $15,00 \mathrm{a}$ & $14,11 \mathrm{~b}$ & $(-)$ \\
\hline
\end{tabular}

Keterangan: Angka pada kolom dan baris diikuti huruf sama menunjukkan tidak berbeda pada tingkat nyata $(\alpha) 5 \%$ menurut uji DMRT; (-): Tidak terjadi interaksi antar faktor.

\subsection{Luas Daun}

Hasil sidik ragam (anova) menunjukkan bahwa tidak terjadi interaksi antara perlakuan takaran arang kesambi dan konsentrasi teh kompos terhadap pertumbuhan dan hasil tanaman bayam hijau untuk pengamatan luas daun. Pemberian arang kesambi dengan takaran 5 t/ha memberikan pengaruh yang beda nyata atau memiliki permukaan daun yang lebih luas (7.921) dibanding 10 t/ha dan kontrol yang memiliki permukaan daun yang lebih sempit. Pemberian teh kompos tidak menunjukkan beda nyata namun pemberian dengan level yang berbeda cenderung meningkatkan luas daun.

Tabel 7. Luas Daun $\left(\mathrm{cm}^{2}\right)$

\begin{tabular}{lllll}
\hline \multicolumn{1}{c}{ Takaran Arang } & \multicolumn{3}{c}{ Konsentrasi Teh Kompos } & \multirow{2}{*}{ Rerata } \\
\cline { 2 - 4 } \multicolumn{1}{c}{ Kesambi } & Kontrol & K5 (1:5) & K10 (1:10) & \\
\hline Kontrol & 4.061 & 3.731 & 5.768 & $4.520 \mathrm{~b}$ \\
$5 \mathrm{t} / \mathrm{ha}$ & 8.520 & 7.435 & 7.808 & $7.921 \mathrm{a}$ \\
$10 \mathrm{t} / \mathrm{ha}$ & 6.712 & 7.394 & 5.734 & $6.613 \mathrm{ab}$ \\
\hline Rerata & $6.431 \mathrm{a}$ & $6.186 \mathrm{a}$ & $6.437 \mathrm{a}$ & $(-)$
\end{tabular}

Keterangan: Angka pada kolom dan baris diikuti huruf sama menunjukkan tidak berbeda pada tingkat nyata $(\alpha) 5 \%$ menurut uji DMRT; (-): Tidak terjadi interaksi antar faktor.

\subsection{Panjang Akar}

Hasil sidik ragam (anova) menunjukkan bahwa tidak terjadi interaksi antara perlakuan takaran arang kesambi dan konsentrasi teh kompos terhadap panjang akar. Rata-rata pemberian arang kesambi menunjukkan tidak beda nyata, dan memiliki nilai tertinggi pada kontrol $(14,97)$, sementara untuk perbandingan konsentrasi teh kompos juga tidak terjadi beda nyata.

\section{Tabel 8. Panjang Akar $(\mathrm{cm})$}

\begin{tabular}{lllll}
\hline \multicolumn{1}{c}{ Takaran Arang } & \multicolumn{3}{c}{ Konsentrasi Teh Kompos } & \multirow{2}{*}{ Rerata } \\
\cline { 2 - 4 } & \multicolumn{1}{c}{ Kontrol } & K5 (1:5) & K10 (1:10) & \\
\hline Kontrol & 14,08 & 15,58 & 15,25 & $14,97 \mathrm{a}$ \\
$5 \mathrm{t} / \mathrm{ha}$ & 13,17 & 9,17 & 14,42 & $12,25 \mathrm{a}$ \\
$10 \mathrm{t} / \mathrm{ha}$ & 13,58 & 9,75 & 15,17 & $12,83 \mathrm{a}$ \\
\hline Rerata & $13,61 \mathrm{a}$ & $11,50 \mathrm{a}$ & $14,94 \mathrm{a}$ & $(-)$ \\
\hline
\end{tabular}

Keterangan: Angka pada kolom dan baris diikuti huruf sama menunjukkan tidak berbeda pada tingkat nyata $(\alpha) 5 \%$ menurut uji DMRT; (-): Tidak terjadi interaksi antar faktor.

\subsection{Berat Segar Tanaman}

Hasil sidik ragam (anova) menunjukkan bahwa terjadi interaksi antara perlakuan takaran arang kesambi dan konsentrasi teh kompos terhadap berat segar tanaman bayam hijau. Pemberian arang kesambi dengan takaran 5 t/ha dan konsentrasi teh kompos 1:5 memiliki bobot segar tanaman paling tinggi (122,30 g) yang berbeda nyata dibanding perlakuan lainnya.

Tabel 9. Berat Segar Tanaman (g)

\begin{tabular}{lllll}
\hline \multirow{2}{*}{ Takaran Arang } & \multicolumn{3}{c}{ Konsentrasi Teh Kompos } & \multirow{2}{*}{ Rerata } \\
\cline { 2 - 4 } & \multicolumn{1}{c}{ Kontrol } & \multicolumn{1}{c}{ K5 $(1: 5)$} & K10 $(1: 10)$ & \\
\hline Kontrol & $44,77 \mathrm{~b}$ & $62,58 \mathrm{~b}$ & $57,70 \mathrm{~b}$ & 55,02 \\
$5 \mathrm{t} / \mathrm{ha}$ & $58,67 \mathrm{~b}$ & $122,30 \mathrm{a}$ & $55,59 \mathrm{~b}$ & 78,85 \\
$10 \mathrm{t} / \mathrm{ha}$ & $66,03 \mathrm{~b}$ & $66,37 \mathrm{~b}$ & $50,00 \mathrm{~b}$ & 60,80 \\
\hline Rerata & 56,49 & 83,75 & 54,43 & $(+)$ \\
\hline
\end{tabular}

Keterangan: Angka pada kolom dan baris diikuti huruf sama menunjukkan tidak berbeda pada tingkat nyata $(\alpha) 5 \%$ menurut uji DMRT; $(+)$ : Terjadi interaksi antar faktor.

\subsection{Berat Kering Tanaman}

Hasil sidik ragam (anova) menunjukkan bahwa tidak terjadi interaksi antara perlakuan takaran arang kesambi dan konsentrasi teh kompos terhadap berat kering tanaman bayam hijau. Bayam hijau yang diberi teh kompos dan arang kesambi memiliki berat kering tanaman cenderung lebih tinggi dibandingkan dengan yang tidak di beri teh kompos dan arang kesambi (kontrol). Data tabel 10 menunjukkan pemberian arang kesambi dengan takaran $5 \mathrm{t} /$ ha memiliki rata-rata berat tertinggi $(27,72)$ dibandingkan pemberian 10 t/ha dan kontrol. Pemberian teh kompos dengan konsentrasi 1:5 menunjukkan beda nyata atau memiliki ratarata berat tertinggi $(27,18)$ dibandingkan 10 ton/ha dan kontrol.

Tabel 10. Berat Kering Tanaman (g)

\begin{tabular}{lllll}
\hline \multicolumn{1}{c}{ Takaran Arang } & \multicolumn{3}{c}{ Konsentrasi Teh Kompos } & \multirow{2}{*}{ Rerata } \\
\cline { 2 - 4 } & Kontrol & K5 (1:5) & K10 (1:10) & \\
\hline Kontrol & 19,06 & 25,07 & 25,19 & $23,11 \mathrm{a}$ \\
$5 \mathrm{t} / \mathrm{ha}$ & 23,58 & 32,40 & 27,17 & $27,72 \mathrm{a}$ \\
$10 \mathrm{t} / \mathrm{ha}$ & 24,41 & 24,06 & 25,25 & $24,58 \mathrm{a}$ \\
\hline Rerata & $22,35 \mathrm{~b}$ & $27,18 \mathrm{a}$ & $25,87 \mathrm{ab}$ & $(-)$ \\
\hline
\end{tabular}

Keterangan: Angka pada kolom dan baris diikuti huruf sama menunjukkan tidak berbeda pada tingkat nyata $(\alpha) 5 \%$ menurut uji DMRT; (-): Tidak terjadi interaksi antar faktor.

\subsection{Berat Segar Tajuk}

Hasil sidik ragam (anova) menunjukkan bahwa terjadi interaksi antara perlakuan takaran arang kesambi dan konsentrasi teh kompos terhadap berat segar tajuk tanaman bayam hijau. Pemberian perlakuan arang kesambi dengan takaran 5 t/ha dan konsentrasi teh kompos 1:5 memiliki bobot segar tajuk paling tinggi $(106,24 \mathrm{~g})$ yang berbeda nyata dengan perlakuan lainnya. 
Tabel 11. Berat Segar Tajuk (g)

\begin{tabular}{|c|c|c|c|c|}
\hline \multirow{2}{*}{$\begin{array}{c}\text { Takaran Arang } \\
\text { Kesambi }\end{array}$} & \multicolumn{3}{|c|}{ Konsentrasi Teh Kompos } & \multirow{2}{*}{ Rerata } \\
\hline & Kontrol & K5 (1:5) & K10 (1:10) & \\
\hline Kontrol & $38,80 \mathrm{~b}$ & $53,37 \mathrm{~b}$ & $48,59 \mathrm{~b}$ & 46,92 \\
\hline $5 \mathrm{t} / \mathrm{ha}$ & $51,52 \mathrm{~b}$ & 106,24 a & $48,40 \mathrm{~b}$ & 68,72 \\
\hline $10 \mathrm{t} / \mathrm{ha}$ & $57,75 \mathrm{~b}$ & $56,80 \mathrm{~b}$ & $41,86 \mathrm{~b}$ & 52,14 \\
\hline Rerata & 49,36 & 72,14 & 46,28 & $(+)$ \\
\hline
\end{tabular}

Keterangan: Angka pada kolom dan baris diikuti huruf sama menunjukkan tidak berbeda pada tingkat nyata $(\alpha) 5 \%$ menurut uji DMRT; $(+)$ : Terjadi interaksi antar faktor.

\subsection{Berat Kering Tajuk}

Hasil sidik ragam (anova) menunjukkan bahwa tidak terjadi interaksi antara perlakuan takaran arang kesambi dan konsentrasi teh kompos terhadap berat kering tajuk tanaman bayam hijau. Bayam hijau yang diberi arang kesambi dan teh kompos memiliki berat kering tajuk cenderung lebih berat dibandingkan tanpa pemberian arang kesambi dan teh kompos. Berdasarkan data Tabel 12. menunjukkan pemberian arang kesambi dengan takaran $5 \mathrm{t} / \mathrm{ha}$ memberikan pengaruh yang beda nyata atau memiliki berat kering tajuk tertinggi $(25,51)$ dibanding pemberian 10 t/ha dan kontrol. pemberian teh kompos dengan konsentrasi 1:5 juga menunjukkan beda nyata atau memiliki berat kering tajuk tertinggi $(25,04)$ dibandingkan 10 ton/ha dan kontrol yang memiliki berat lebih ringan.

\section{Tabel 12. Berat Kering Tajuk (g)}

\begin{tabular}{|c|c|c|c|c|}
\hline \multirow{2}{*}{$\begin{array}{c}\text { Takaran Arang } \\
\text { Kesambi }\end{array}$} & \multicolumn{3}{|c|}{ Konsentrasi Teh Kompos } & \multirow{2}{*}{ Rerata } \\
\hline & Kontrol & K5 (1:5) & K10 (1:10) & \\
\hline Kontrol & 18,23 & 22,92 & 23,54 & $21,56 \mathrm{~b}$ \\
\hline $5 \mathrm{t} / \mathrm{ha}$ & 22,20 & 29,67 & 24,65 & $25,51 \mathrm{a}$ \\
\hline $10 \mathrm{t} / \mathrm{ha}$ & 22,53 & 22,52 & 22,39 & $22,48 \mathrm{ab}$ \\
\hline Rerata & $20,98 \mathrm{~b}$ & $25,04 \mathrm{a}$ & $23,53 \mathrm{ab}$ & $(-)$ \\
\hline
\end{tabular}

Keterangan: Angka pada kolom dan baris diikuti huruf sama menunjukkan tidak berbeda pada tingkat nyata ( $\alpha$ ) $5 \%$ menurut uji DMRT; (-): Tidak terjadi interaksi antar faktor.

\subsection{Berat Segar Akar}

Hasil sidik ragam (anova) menunjukkan bahwa tidak terjadi interaksi antara perlakuan takaran arang kesambi dan konsentrasi teh kompos terhadap berat segar akar. Pemberian arang kesambi rata-rata menunjukkan tidak beda nyata dan memiliki nilai tertinggi pada takaran $5 \mathrm{t} / \mathrm{ha}(5,09)$ dibanding pemberian 10 t/ha dan kontrol. pemberian teh kompos juga menunjukkan beda nyata pada konsentrasi 1:5 (5,84).

\section{Tabel 13. Berat segar akar (g)}

\begin{tabular}{lllll}
\cline { 1 - 4 } \multicolumn{1}{c}{ Takaran Arang } & \multicolumn{3}{c}{ Konsentrasi Teh Kompos } & \multirow{2}{*}{ Rerata } \\
\cline { 2 - 4 } Kosambi & Kontrol & K5 $(1: 5)$ & K10 (1:10) & \\
\hline Kontrol & 2,98 & 4,61 & 4,56 & $4,05 \mathrm{a}$ \\
t/ha & 3,58 & 8,11 & 3,59 & $5,09 \mathrm{a}$ \\
$10 \mathrm{t} / \mathrm{ha}$ & 4,14 & 4,79 & 4,12 & $4,35 \mathrm{a}$ \\
\hline Rerata & $3,57 \mathrm{~b}$ & $5,84 \mathrm{a}$ & $4,09 \mathrm{~b}$ & $(-)$ \\
\hline
\end{tabular}

Keterangan: Angka pada kolom dan baris diikuti huruf sama menunjukkan tidak berbeda pada tingkat nyata $(\alpha) 5 \%$ menurut uji DMRT; (-): Tidak terjadi interaksi antar faktor.

\subsection{Berat Kering Akar}

Hasil sidik ragam (anova) menunjukkan bahwa tidak terjadi interaksi dan tidak ada beda nyata antara perlakuan takaran arang kesambi dan konsentrasi teh kompos terhadap berat kering akar, tetapi rata-rata pemberian arang kesambi menunjukkan nilai tidak beda nyata dan pemberian level dengan takaran $5 \mathrm{t} / \mathrm{ha}$ memiliki nilai tertinggi $(1,11)$ dibanding pemberian 10 t/ha dan kontrol. Ratarata Konsentrasi Teh Kompos tidak beda nyata, namun pemberian teh kompos dengan konsentrasi 1:10 juga menunjukkan nilai tertinggi $(1,21)$.

Tabel 14. Berat Kering Akar (g)

\begin{tabular}{lllll}
\hline \multicolumn{1}{c}{ Takaran Arang } & \multicolumn{3}{c}{ Konsentrasi Teh Kompos } & \multirow{2}{*}{ Rerata } \\
\cline { 2 - 4 } & \multicolumn{1}{c}{ Kontrol } & K5 $(1: 5)$ & K10 $(1: 10)$ & \\
\hline Kontrol & 0,42 & 1,07 & 0,92 & $0,80 \mathrm{a}$ \\
$5 \mathrm{t} / \mathrm{ha}$ & 0,69 & 1,37 & 1,26 & $1,11 \mathrm{a}$ \\
$10 \mathrm{t} / \mathrm{ha}$ & 0,94 & 0,77 & 1,43 & $1,05 \mathrm{a}$ \\
\hline Rerata & $0,68 \mathrm{a}$ & $1,07 \mathrm{a}$ & $1,21 \mathrm{a}$ & $(-)$ \\
\hline
\end{tabular}

Keterangan: Angka pada kolom dan baris diikuti huruf sama menunjukkan tidak berbeda pada tingkat nyata $(\alpha) 5 \%$ menurut uji DMRT; (-): Tidak terjadi interaksi antar faktor.

\subsection{Rasio Tajuk Akar}

Hasil sidik ragam (anova) menunjukkan bahwa tidak terjadi interaksi dan tidak ada beda nyata antara perlakuan takaran arang kesambi dan konsentrasi teh kompos terhadap rasio tajuk akar, tetapi tanpa pemberian arang kesambi (kontrol) memiliki nilai tertinggi $(37,67)$ dibanding 10 t/ha dan 5t/ha. Rata-rata pada konsentrasi teh kompos menunjukkan nilai yang tidak beda nyata, namun tanpa pemberian teh kompos menunjukkan nilai tertinggi $(40,13)$.

\begin{tabular}{|c|c|c|c|c|}
\hline \multirow{2}{*}{$\begin{array}{c}\text { Takaran Arang } \\
\text { Kesambi }\end{array}$} & \multicolumn{3}{|c|}{ Konsentrasi Teh Kompos } & \multirow[b]{2}{*}{ Rerata } \\
\hline & Kontrol & K5 (1:5) & K10 (1:10) & \\
\hline Kontrol & 54,39 & 29,52 & 29,11 & $37,67 \mathrm{a}$ \\
\hline $5 \mathrm{t} / \mathrm{ha}$ & 36,24 & 24,15 & 28,69 & $29,69 \mathrm{a}$ \\
\hline $10 \mathrm{t} / \mathrm{ha}$ & 29,77 & 31,44 & 26,50 & $29,23 \mathrm{a}$ \\
\hline Rerata & $40,13 \mathrm{a}$ & $28,37 \mathrm{a}$ & $28,10 \mathrm{a}$ & $(-)$ \\
\hline
\end{tabular}

\subsection{Berat Segar Tanaman Per Hektar}

Hasil sidik ragam (anova) menunjukkan bahwa tidak terjadi interaksi antara perlakuan takaran arang kesambi dan konsentrasi teh kompos terhadap pertumbuhan tanaman bayam hijau. Bayam hijau yang diberi teh kompos dan arang kesambi memiliki berat segar tanaman per petak paling tinggi dibanding kontrol, namun pemberian arang kesambi dengan takaran 5 t/ha memberikan pengaruh yang berbeda nyata dan menunjukkan nilai tertinggi $(7,12)$ dibanding 10 tha dan kontrol. pemberian teh kompos dengan konsentrasi 1:5 juga menunjukkan beda nyata dan menunjukkan nilai tertinggi $(7,39)$.

\section{Tabel 16. Berat Segar Tanaman t/ha}

\begin{tabular}{lllll}
\hline \multicolumn{1}{c}{ Takaran Arang } & \multicolumn{3}{c}{ Konsentrasi Teh Kompos } & \multirow{2}{*}{ Rerata } \\
\cline { 2 - 4 } Kesambi & Kontrol & K5 $(1: 5)$ & K10 $(1: 10)$ & \\
\hline Kontrol & 3,76 & 7,05 & 5,34 & $5,38 \mathrm{a}$ \\
$5 \mathrm{t} / \mathrm{ha}$ & 5,49 & 7,63 & 8,24 & $7,12 \mathrm{a}$ \\
$10 \mathrm{t} / \mathrm{ha}$ & 4,91 & 7,50 & 5,58 & $6,00 \mathrm{a}$ \\
\hline Rerata & $4,72 \mathrm{~b}$ & $7,39 \mathrm{a}$ & $6,39 \mathrm{ab}$ & $(-)$ \\
\hline
\end{tabular}

Keterangan: Angka pada kolom dan baris diikuti huruf sama menunjukkan tidak berbeda pada tingkat nyata $(\alpha) 5 \%$ menurut uji DMRT; (-): Tidak terjadi interaksi antar faktor

\subsection{Berat Kering Tanaman Per Hektar}

Hasil sidik ragam (anova) menunjukkan bahwa tidak terjadi interaksi antara perlakuan takaran arang kesambi dan konsentrasi teh kompos terhadap pertumbuhan dan hasil tanaman bayam. Pemberian arang kesambi rata-rata menunjukkan tidak beda nyata dan pemberian dengan takaran $5 \mathrm{t} / \mathrm{ha}$ memiliki nilai tertinggi $(0,87 \mathrm{t} / \mathrm{ha}$ ) dibanding pemberian $10 \mathrm{t} / \mathrm{ha}$ dan kontrol. pemberian teh kompos dengan konsentrasi 1:5 juga menunjukkan beda nyata dan memiliki nilai tertinggi $(0,85 \mathrm{t} / \mathrm{ha})$.

\section{Tabel 17. Berat Kering Tanaman (t/ha)}

\begin{tabular}{lllll}
\hline Takaran Arang & \multicolumn{3}{c}{ Konsentrasi Teh Kompos } & \multirow{2}{*}{ Rerata } \\
\cline { 2 - 4 } \multicolumn{1}{c}{ Kesambi } & Kontrol & \multicolumn{1}{c}{ K5 $(1: 5)$} & K10 (1:10) & \\
\hline Kontrol & 0,58 & 0,88 & 0,72 & $0,73 \mathrm{a}$ \\
$5 \mathrm{t} / \mathrm{ha}$ & 0,72 & 0,82 & 1,07 & $0,87 \mathrm{a}$ \\
$10 \mathrm{t} / \mathrm{ha}$ & 0,63 & 0,84 & 0,72 & $0,73 \mathrm{a}$ \\
\hline Rerata & $0,64 \mathrm{~b}$ & $0,85 \mathrm{a}$ & $0,84 \mathrm{a}$ & $(-)$
\end{tabular}

Keterangan: Angka pada kolom dan baris diikuti huruf sama menunjukkan tidak berbeda pada tingkat nyata $(\alpha) 5 \%$ menurut uji DMRT; (-): Tidak terjadi interaksi antar faktor

\subsection{Indeks Panen}

Hasil sidik ragam (Anova) menunjukkan bahwa tidak terjadi interaksi dan tidak berbeda nyata antara perlakuan takaran arang kesambi dan konsentrasi teh kompos terhadap indeks panen. Pemberian arang kesambi rata-rata menunjukkan nilai yang tidak beda nyata. Pemberian arang kesambi dengan takaran 5 ton/ha memberikan nilai tertinggi $(99,41)$ dibanding pemberian 10 t/ha dan kontrol. pemberian teh kompos juga menunjukkan nilai yang tidak beda nyata, namun pemberian teh kompos dengan konsentrasi 1:10 memiliki nilai tertinggi $(99,45)$.

Tabel 18. Indeks Panen (\%)

\begin{tabular}{lllll}
\hline Takaran Arang & \multicolumn{3}{c}{ Konsentrasi Teh Kompos } & \multirow{2}{*}{ Rerata } \\
\cline { 2 - 4 } \multicolumn{1}{c}{ Kesambi } & Kontrol & K5 (1:5) & K10 $(1: 10)$ & \\
\hline Kontrol & 99,29 & 99,46 & 99,28 & $99,34 \mathrm{a}$ \\
$5 \mathrm{t} / \mathrm{ha}$ & 99,47 & 99,11 & 99,63 & $99,41 \mathrm{a}$ \\
$10 \mathrm{t} / \mathrm{ha}$ & 99,28 & 99,40 & 99,44 & $99,37 \mathrm{a}$ \\
\hline Rerata & $99,35 \mathrm{a}$ & $99,32 \mathrm{a}$ & $99,45 \mathrm{a}$ & $(-)$ \\
\hline
\end{tabular}

Keterangan: Angka pada kolom dan baris diikuti huruf sama menunjukkan tidak berbeda pada tingkat nyata $(\alpha) 5 \%$ menurut uji DMRT; (-): Tidak terjadi interaksi antar faktor

\subsection{Pembahasan}

Hasil sidik ragam (anova) menunjukkan bahwa tidak terjadi interaksi dari setiap parameter pertumbuhan, yang diberi teh kompos pertumbuhannya jauh lebih baik dibandingkan dengan bayam hijau yang tidak diberi teh kompos (kontrol). Hasil penelitian menunjukkan bahwa bayam hijau yang diberi teh kompos dengan perbandingan $1: 5$ dan pemberian arang kesambi dengan takaran 5 ton /ha dapat meningkatkan pertumbuhan tanaman bayam hijau yang dapat diekspresikan berat segar tanaman, tinggi tanaman, jumlah daun, diameter batang dan luas daun, dan yang memiliki hasil secara nyata memberikan pertumbuhan 
yang lebih optimal terhadap tanaman bayam hijau yaitu pada bobot segar tanaman $(122,30 \mathrm{~g})$ dan bobot segar tajuk $(106,24 \mathrm{~g})$ lebih tinggi dibandingkan dengan kontrol.

Pemberian teh kompos dan arang kesambi divariasikan dengan tiga macam konsentrasi perbandingan. Hasil penelitian membuktikan bahwa pemberian teh kompos dengan konsentrasi perbandingan 1:5 dan pemberian arang kesambi dengan takaran 5 ton/ha memberikan pertumbuhan yang optimal, oleh karena itu dapat diterapkan dalam budidaya bayam karena dapat meningkatkan pertumbuhan maupun hasil tanaman.

Selain itu pertumbuhan tanaman bayam hijau menjadi optimal karena dipengaruhi oleh beberapa faktor lingkungan lainnya yaitu suhu tanah, DHL tanah dan $\mathrm{pH}$ tanah.

\section{Simpulan}

Aplikasi teh kompos meningkatkan pertumbuhan tanaman, berat segar tanaman, tinggi tanaman, jumlah daun, diameter batang, dan luas daun, memiliki hasil yang lebih tinggi dibandingkan dengan kontrol. Teh kompos dengan perbandingan konsentrasi 1:5 dan aplikasi arang kesambi dengan takaran 5ton/ha memberikan pertumbuhan vegetatif yang paling baik yaitu pada bobot segar tanaman $(122,30 \mathrm{~g})$ dan bobot segar tajuk $(106,24 \mathrm{~g})$.

\section{Pustaka}

Bria, D. 2016. Pengaruh Jenis dan Konsentrasi Teh Kompos Terhadap Pertumbuhan dan Hasil Bayam Merah (Alternanthera amoena, Voss) Savana Cendana, 1(03): 108-111.

Budhyastoro, T., Tala'ohu, S.H. \& Watung, R.L. 2006. Pengukuran Suhu Tanah. Sifat Fisik Tanah dan Metode Analisisnya. Bogor: Balai Besar Penelitian dan Pengembangan Sumberdaya Lahan Pertanian.

Gomez, K.A. \& Gomez, A.A. 1984. Statistical Procedures for Agricultural Research. New York: John Wiley \& Sons.

Irwan, H.H., Wahyudi, I. \& Isrun 2015. Pengaruh Beberapa Jenis Bokashi Terhadap Serapan Nitrogen Tanaman Jagung Manis (Zeamays saccarata) Pada Entisols Sidera. Agrotekbis, 3(2): 141-148.

Ogawa, M. 1994. Symbiosis of people and nature in the tropics. Farming Japan, 28(5): 10-34.

Rukmana, R. 1994. Bayam, Bertanam \& Pengolahan Pascapanen. Yogyakarta: Kanisius.

Sinaga, D. 2010. Pembuatan Pupuk Cair dari Sampah Organik dengan Menggunakan Boisca sebagai Starter. Skripsi. Medan: Fakultas Pertanian, Universitas Sumatera Utara.

Suriatna 2002. Pupuk dan Pemupukan. Jakarta: Mediatama Sarana Perkasa.

Yadav, A., Yadav, T. \& Chaudhary, B. 1979. Path coefficient analysis of the association of physiological traits with grain yield and harvest index in greengram [India]. Indian Journal of Agricultural Sciences, (49): 86-90.

Yuli, A., Harlia, E. \& Hamidah, I. 2003. Identifikasi Jamur dan Bakteri pada Proses Pengomposan Kotoran Sapi Perah. Jurnal Ilmu Ternak, 3(2). 